\title{
Role of nutrients in metabolic syndrome: a 2017 update
}

This article was published in the following Dove Press journal: Nutrition and Dietary Supplements

\author{
Hua J Kern \\ Susan Hazels Mitmesser \\ The Nature's Bounty Co., \\ Ronkonkoma, NY, USA
}

Correspondence: Hua J Kern

The Nature's Bounty Co., 2100

Smithtown Avenue, Ronkonkoma, NY

II779, USA

Tel + I 63I 2003460

Email carinakern@nbty.com

\begin{abstract}
Metabolic syndrome (MetS) and its associated chronic disorders including cardiovascular disease and type 2 diabetes are public health concerns in the USA and worldwide. "Good health is an investment in economic growth," and nutrition is one of the recommended preventive measures to manage these chronic diseases. However, it is unclear whether and to what extent nutrients could be beneficial to the improvement of MetS. To help answer this question, we performed a literature review of the emerging human data on single nutrients and MetS: PubMed was searched from January 1, 2005 to June 12, 2017, using a combination of the following keywords: "nutrient" OR "vitamin" OR "mineral” OR "nutraceutical” AND "metabolic syndrome." The summary of literature comprises macronutrients (proteins/amino acids, fatty acids, fibers, and sugar), micronutrients (antioxidant vitamins, vitamin D, folate, magnesium, and chromium), polyphenols (flavonoids, resveratrol, isoflavones, and chlorogenic acid), and other compounds ( $\alpha$-lipoic acid, benfotiamine, fucoxanthin, policosanol, and stanols). Bearing a holistic approach in mind, we also highlighted select lifestyle factors that may contribute to MetS (such as circadian rhythm and nutrition in early life). Observational studies have generated positive evidence supporting the beneficial role of numerous nutrients in MetS. Although the results of some clinical trials are consistent with the observational data, causality is not always clear or consistent across trials. Both nutrition and health are complex and dynamic systems with a hierarchical nature. When we design confirmatory trials to investigate nutrient(s) and MetS, instead of the traditional "single-nutrient" concept, it is worth considering a holistic approach to integrate groups or classes of nutrients, lifestyle influencers (ie, diet and physical activity), and population relevance (ie, healthy, at-risk, or diseased).
\end{abstract}

Keywords: nutrient, metabolic syndrome, obesity, hypertension, dyslipidemia, insulin resistance

\section{Introduction}

Metabolic syndrome (MetS) is a constellation of interrelated metabolic abnormalities that are major risk factors for the development of cardiovascular disease (CVD) and type 2 diabetes mellitus (T2DM). There are various definitions of MetS (eg, World Health Organization, the International Diabetes Federation, and the US National Cholesterol Education Program's Adult Treatment Panel III [NCEP/ATP III]). ${ }^{1}$ The most widely used definition (from the NCEP/ATP III) is defined as the presence of three or more of the following metabolic disorders: central obesity (waist circumference: $\geq 102 \mathrm{~cm}$ for men, $\geq 88 \mathrm{~cm}$ for women), dyslipidemia (high-density lipoprotein cholesterol [HDL]: $<40 \mathrm{mg} / \mathrm{dL}$ for men, $<50 \mathrm{mg} / \mathrm{dL}$ for women; or triglycerides [TGs] $\geq 150 \mathrm{mg} / \mathrm{dL}$ ), hypertension (systolic/diastolic blood pressure $\geq 130 / 85 \mathrm{mmHg}$ ), and insulin resistance (elevated fasting blood glucose $\geq 110 \mathrm{mg} / \mathrm{dL}$ ). ${ }^{2}$ 
MetS and its associated chronic diseases are public health concerns in the USA and worldwide. About $34 \%$ of US adults have MetS, ${ }^{3}$ and $9.3 \%$ of the US population (29.1 million) are diabetic. ${ }^{6}$ MetS is associated with an increase in risks of developing CVD and T2DM over the next 5-10 years. ${ }^{4}$ Each year, one in every four deaths among Americans is attributed to heart disease, totaling about 610,000 deaths annually. ${ }^{5}$ The annual combined cost (direct and indirect expenditures) of CVD (hypertension, heart disease, and stroke) and diabetes in the USA was $\$ 650$ billion in 2003 and is projected to be $\$ 1.96$ trillion by 2023 . $^{7}$ Prevention and early management of MetS may help manage these disease burdens and the associated health care cost worldwide.

"Good health is an investment in economic growth,"7 and nutrition is one of the recommended preventive measures to help manage chronic morbidities. ${ }^{8}$ However, it is unclear whether and to what extent single nutrients could be beneficial to MetS. To help address this question, we reviewed relevant literature in the past decade and summarize emerging human data for single nutrients' influence on MetS in this review.

\section{Literature search methods}

We searched PubMed from January 1, 2005 to June 12, 2017, by using a combination of the following keywords: "nutrient" OR “vitamin" OR "mineral” OR "nutraceutical" AND "metabolic syndrome." Table S1 summarizes the reviews, systematic reviews, and meta-analyses of human data published in English.

The focus of this review is on the specific role of individual nutrients in the prevention or treatment of MetS among US adults. In the section of "Literature summary/ Discussion," individual nutrients are grouped into one of the following four categories: macronutrients, micronutrients, polyphenols, and other compounds. Specific dietary patterns, food groups, gene/drug-nutrient interactions, biochemical/ molecular mechanism, or pediatric studies are not included in the present review.

\section{Literature summary/discussion}

Figure 1 summarizes the literature data on key nutrients and MetS parameters

\section{Macronutrients}

\section{Proteins/amino acids}

A review of human acute feeding trials and relevant metaanalyses concludes that, compared with lower-protein diets, higher-protein energy-restriction diets containing $1.2-1.6 \mathrm{~g}$ protein $/ \mathrm{kg} /$ day improve appetite, weight management (eg, loss of fat mass while maintaining lean muscle), and some cardiometabolic risk factors (eg, lowering fasting TGs) over a short term ( $<1$ year). ${ }^{9,10}$ The long-term data $(\geq 1$ year) are less consistent primarily due to discrepant dietary compliance, but there is persistent evidence supporting the benefits of increased protein consumption on weight maintenance. ${ }^{9,10}$ Hypothesized mechanisms of action include an increase in thermogenesis and metabolic rate and a modest satiety effect after the consumption of protein-rich meals. ${ }^{9,10}$

Certain amino acids including glutamine derivatives, alanine and arginine, may influence pancreatic $\beta$-cell function (eg, insulin secretion), but the mechanism is not completely understood. ${ }^{11}$ Human studies report that consumption of dairy products rich in branched-chain amino acids (BCAAs; leucine, isoleucine, and valine) or whey/casein protein is associated with improved diabetic parameters (eg, fasting insulin levels) among obese and T2DM individuals. ${ }^{11,12}$

When human subjects with hypercholesterolemia consumed lupin protein ( $25 \mathrm{~g} /$ day) with a mixed diet for 28 days, their plasma levels of total cholesterol (TC), TGs, and lowdensity lipoprotein cholesterol (LDL) decreased. ${ }^{2}$ Animal or in vitro data have reported benefits of peptides (synthesized or extracted from dietary proteins) for lipid metabolism, but human data are limited.

\section{Fatty acids}

According to recent evidence, saturated and trans fatty acids have deleterious influences on metabolic health. ${ }^{4,13-15}$ In contrast, unsaturated fatty acids including monounsaturated fatty acids and omega-3/omega-6 polyunsaturated fatty acids (PUFA) improve metabolic parameters (eg, blood pressure, lipid profile, glycemic control, and insulin sensitivity). ${ }^{4,13-15}$ Diets rich in conjugated linoleic acid (CLA), in particular the cis-9 trans-11-CLA isomer, have been shown to improve the markers of metabolic and insulin sensitivity in adipose tissue and liver, indicating a potential benefit for metabolic health. ${ }^{15}$ It is important to note that these benefits are linked to the consumption of the dietary components as part of a specific diet, suggesting a need for human studies to confirm the benefit of single nutrients. ${ }^{13}$ In addition, more data are needed to define the optimal composition of dietary fatty acids (eg, amount and type) to which metabolic health will be affected. ${ }^{4}$

The Japanese have the highest intake of omega-3 fatty acids in the world. Even in this population, omega-3 and omega- 6 fatty acids have been reported to provide some protection against cardiac and major coronary events. ${ }^{16}$ Based 


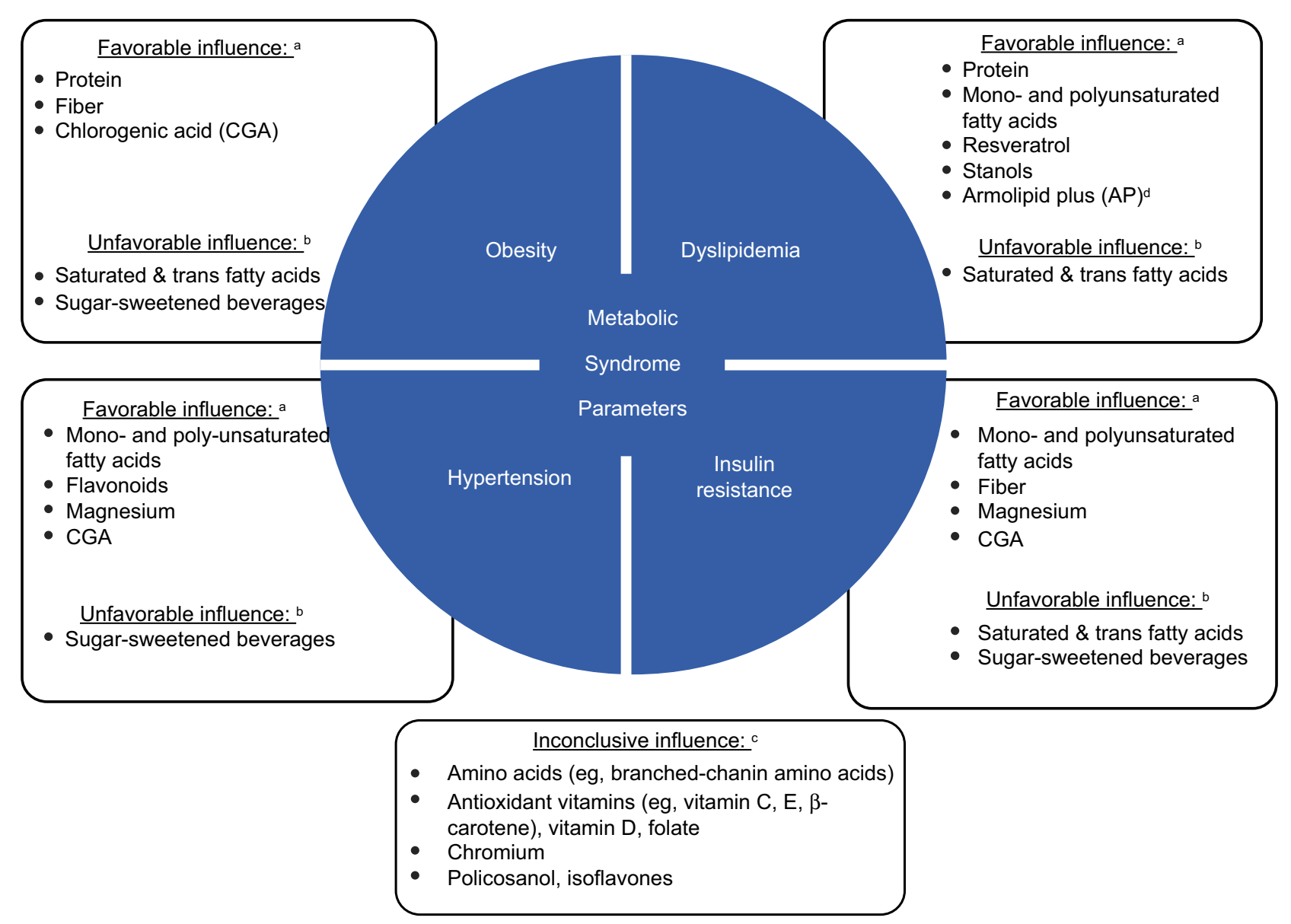

Figure I Select nutrients on metabolic syndrome parameters.

Notes: aFavorable influence: human data indicate postive influence of a single or group of nutrient(s) on metabolic syndrome parameters. bUnfavorable influence: human data indicate negative influence of a single or group of nutrient(s) on metabolic syndrome parameters. Inconclusive influence: human data are inconsistent or lacking. ${ }^{\mathrm{A}}$ Armolipid plus (AP): a commercial dietary supplement combining policosanol, berberine, red yeast rice extract, folic acid, coenzyme Q10, and asthaxantine.

on evidence from randomized controlled trials (RCTs), the American Heart Association concluded that omega-3 fatty acids have been demonstrated to reduce the risks of CVD events in patients with coronary artery diseases. ${ }^{14}$ While there is little direct evidence that omega-3 PUFA supplementation affects insulin sensitivity in humans, epidemiological studies found that habitual fish intake is associated with the reduced incidence of T2DM. ${ }^{15}$

\section{Fiber}

Observational data indicate an inverse relationship between dietary fiber intake (from cereals and whole grain) and body weight/diabetes/CVD. ${ }^{14}$ According to a meta-analysis of six prospective studies, an increase in whole grain consumption by two servings per day may reduce the risk of diabetes by $21 \% .{ }^{14}$ Fiber is commonly classified as soluble or insoluble, based on its solubility in water. Soluble dietary fiber is associated with improved glycemic control and insulin sensitivity in both diabetic and healthy subjects, generally attributable to its viscous properties. It, however, does not appear to reduce the risk of T2DM. ${ }^{14}$ In contrast, insoluble fiber reduces the risk of diabetes, even though it has negligible influence on postprandial glucose levels. ${ }^{14}$

\section{Sugar}

Sugar-sweetened beverages (SSBs) contain caloric sweeteners such as sucrose, high-fructose corn syrup, or fruit juice concentrates and are the primary source of added sugar in the US diet. ${ }^{17}$ A meta-analysis pooled data from 11 prospective cohort studies and included 19,431 participants for MetS (5,803 cases) and 310,819 for T2DM (15,043 cases). Compared with individuals who rarely consume SSB (none or $<1$ serving/month), those 
who consumed one to two servings per day were at a higher risk of developing MetS (relative risk $[\mathrm{RR}]=1.20$; 95\% confidence interval $[\mathrm{CI}]=1.02-1.42)$ and $\mathrm{T} 2 \mathrm{DM}(\mathrm{RR}=1.26 ; 95 \%$ $\mathrm{CI}=1.12-1.41) .{ }^{17}$ In addition, a longitudinal cohort followed $>88,000$ women for 24 years and found that consumption of $\geq 2 \mathrm{SSBs} /$ day was associated with a $35 \%$ increased risk for coronary heart disease compared with infrequent consumers $(\mathrm{RR}=1.35 ; 95 \% \mathrm{CI}=1.1-1.7) .{ }^{17}$ A number of prospective cohort studies have also reported positive associations between SSB consumption and incidence of hypertension. ${ }^{17}$

In response to convincing evidence linking SSBs to metabolic disorders, organizations such as the American Heart Association have called for reducing the consumption of SSBs. In addition, the US Food and Drug Administration (US FDA) announced new food-labeling rules stating that the content of added sugar must be called out on food labels in the near future. Low-energy sweeteners are emerging as a potential replacement for traditional sugar. In vivo human studies have extensively studied the influence of this group on metabolic health and indicate inconsistent evidence linking low-energy sweeteners to unfavorable metabolic changes (eg, increased appetite, altered glucose homeostasis, or blood pressure). ${ }^{18}$

\section{Micronutrients}

\section{Antioxidant vitamins}

Systemic inflammation and oxidative stress are core mechanisms connecting energy overload and obesity to insulin resistance and consequent metabolic disorders. ${ }^{14,19}$ Antioxidant compounds can modulate oxidative stress and potentially prevent health complications that are associated with oxidative damage. ${ }^{19}$ As an example, vitamin $\mathrm{A}$ in the form of retinol not only influences immune function, but can also reverse chronic inflammation by reducing the level of adipocytokines according to in vitro and in vivo data. ${ }^{20}$ Animal data indicate retinol-binding protein (RBP4; the transport protein for retinol) concentrations are inversely related to insulin sensitivity. Furthermore, obese or diabetic individuals are found to have increased serum levels of RBP4. ${ }^{20}$

Epidemiological studies have found that diets rich in antioxidants (such as vitamin $\mathrm{C}$, vitamin $\mathrm{E}$, and $\beta$-carotene) have advantageous effects on glucose metabolism and the prevention of diabetes ${ }^{19}$ and are associated with a reduced risk of CVD. ${ }^{16}$ Observational data further suggest that higher dietary intake or supplementation of antioxidants (vitamins A, C, and $\mathrm{E}$, folic acid, niacin, $\beta$-carotene, selenium, and zinc) reduces CVD-related mortalities and morbidities over a minimum of 2-year intervention. ${ }^{16}$ Furthermore, natural forms of these vitamins may be more efficacious than synthetic forms. ${ }^{14,21}$ However, RCTs indicate mixed results regarding the role of any single antioxidant or a combination of antioxidants in metabolic health. ${ }^{14,21}$

\section{Vitamin D}

T2DM is associated with systemic inflammation, impaired insulin secretion, and insulin resistance. ${ }^{20}$ Experimental data indicate that vitamin $\mathrm{D}$ improves pancreatic function through the induction of insulin synthesis in the islet cells, stimulating the expression of insulin receptors, regulating calcium influx into pancreatic $\beta$ cells, and inhibiting the generation of proinflammatory cytokines to decrease systemic inflammation. ${ }^{20}$ It is estimated that $25 \%-57 \%$ of US adults and 1 billion people worldwide are vitamin D-insufficient or vitamin D-deficient, ${ }^{22}$ with ethnic minorities having higher prevalence of vitamin D insufficiency compared with Caucasian counterparts. ${ }^{23}$

Many observational data (including US National Health and Nutrition Examination Survey [NHANES]) have reported that vitamin $\mathrm{D}$ status (dietary intake and blood concentrations) is inversely related to the risk or prevalence of MetS, hypertension, obesity, T2DM, and CVD. ${ }^{16,20,22-26}$ A meta-analysis pooled data from 18 prospective studies with a total sample size of 210,107 participants $(15,899$ metabolic events) and a median follow-up of 10 years (range $=3-22$ years). Compared with individuals with the lowest baseline vitamin D level (bottom third), those with the highest baseline vitamin D status (top third) were at a lower risk of developing MetS $(\mathrm{RR}=0.86 ; 95 \% \mathrm{CI}=0.80-0.92)$ and T2DM $(\mathrm{RR}=0.81 ; 95 \% \mathrm{CI}=0.71-0.92) .{ }^{25,27}$ Similarly, another meta-analysis of observational and clinical trials concluded an inverse association between vitamin D status, calcium or dairy intake, and the prevalence or incidence of MetS/T2DM (odds ratios [ORs] comparing highest to lowest 25-hydroxyvitamin D [25(OH)D]: 0.36 [95\% CI $=0.16-0.80]$ for T2DM prevalence and $0.82[95 \% \mathrm{CI}=0.72-0.93]$ for T2DM incidence; ORs for highest vs lowest calcium/diary intake: 0.71 [95\% CI $=0.57-0.89]$ for MetS prevalence and 0.86 [95\% CI $=0.79-0.93]$ for MetS incidence).${ }^{28}$ Furthermore, a meta-analysis of 16 cross-sectional studies reported an increment of $25 \mathrm{nmol} / \mathrm{L}$ blood $25(\mathrm{OH}) \mathrm{D}$ to be associated with a risk reduction of $13 \%$ for MetS among adults aged $\geq 18$ years $(\mathrm{OR}=0.87 ; 95 \% \mathrm{CI}=0.83-0.92) .{ }^{29}$ It should be noted that this inverse association does not appear to be significant in cohort or nested case-control studies $(n=2)$, suggesting that more longitudinal and RCT data are needed to confirm causality. ${ }^{29}$ 
The benefits of vitamin D supplementation on MetS and related medical conditions are not conclusive. For combined vitamin $\mathrm{D}$ and calcium supplementation, intervention trials suggest a benefit only in high-risk populations (eg, with glucose intolerance). ${ }^{28}$ Vitamin D supplementation among high-risk individuals is reported to reduce the incidence of $\mathrm{T} 2 \mathrm{DM}$, indicating a protective role against diabetes.$^{28}$ However, results from RCTs have not shown consistent clinical improvement when supplemented with vitamin $\mathrm{D}$, which may be due to a small sample size, an inappropriate vitamin D dose, baseline vitamin D status inconsistency, gene polymorphism (eg, related to vitamin D receptor), and/or poor compliance..$^{20,30,31}$ Therefore, vitamin D supplementation is not recommended for the prevention or treatment of diabetes due to insufficient evidence. ${ }^{31}$ Well-designed intervention trials targeting generally healthy and at-risk populations are needed to confirm causality. ${ }^{27,31}$

\section{Folate and Biotin}

Epidemiological data have linked folate deficiency to an increased risk and incidence of CVD. Furthermore, serum folate levels appear to be lower among overweight or obese people, indicating a relationship between folate status and adiposity. ${ }^{32}$ However, temporal and causal associations remain uncertain. Future studies focusing on populations with low folate status and folate supplementation as the primary prevention measures are recommended.

A potential synergy between biotin and folic acid in repressing proinflammatory cytokines has been reported in some cell culture experiments..$^{20}$ Relevant human data are currently lacking.

\section{Magnesium}

Magnesium is the fourth most abundant essential mineral in the body and is involved in $>300$ metabolic reactions, including protein/DNA/RNA synthesis, cellular energy production, and cell growth and reproduction. ${ }^{33}$ There is evidence indicating the effective use of magnesium in the treatment of certain medical conditions, including eclampsia, preeclampsia, migraine, severe asthma, and constipation. ${ }^{33}$

A recent meta-analysis of 34 RCTs (2,028 participants) revealed magnesium supplementation at a median dose of 368 $\mathrm{mg}$ /day for a median duration of 3 months to be associated with a reduction of $2 \mathrm{mmHg}(95 \% \mathrm{CI}=0.43-3.58)$ and 1.78 $\mathrm{mmHg}(95 \% \mathrm{CI}=0.73-2.82)$ in systolic and diastolic blood pressure, respectively, ${ }^{34}$ suggesting an anti-hypertensive effect with magnesium supplementation.
Diabetic patients appear to have a higher incidence of hypomagnesaemia than nondiabetics (14\%-48\% vs $3 \%-15 \%$, respectively), ${ }^{35}$ and epidemiological data suggest an inverse correlation between a magnesium-rich diet and fasting insulin level and risk of diabetes. ${ }^{14,36}$ In a recent meta-analysis of 13 prospective cohort studies $(536,318$ subjects and 24,516 diabetes cases), magnesium intake was inversely correlated to the risk of T2DM ( $\mathrm{RR}=0.78 ; 95 \%$ $\mathrm{CI}=0.73-0.84$ ) in a dose-response manner. ${ }^{39}$ Magnesium supplementation has been demonstrated to improve insulin sensitivity and metabolic control among people with T2DM or insulin resistance in a few RCTs..$^{35,36}$

Dietary magnesium intakes and serum levels are inversely associated with the risk of CVD and all-cause mortality according to observational data and a meta-analysis of 19 prospective studies (532,979 participants). ${ }^{35}$ Cross-sectional and prospective studies also report that low urinary magnesium excretion, an indicator of dietary magnesium intake, is associated with a higher risk of developing hypertension and CVD. ${ }^{35}$ However, clinical trials have not confirmed such beneficial effects of magnesium supplementation. ${ }^{35}$ In addition, observational data indicate an inverse association between magnesium status and the risk of MetS among adults, but this potential benefit needs further investigation. ${ }^{33-37}$

\section{Chromium}

Trivalent chromium is the form found in foods and nutrient supplements, with chromium picolinate considered the most stable and bioavailable supplemental form in the market. ${ }^{38}$ It is difficult to assess the intakes of chromium from food sources partially due to the lack of standardized analytical methods, and chromium dietary intake data are currently not available in standard databases (eg, NHANES). ${ }^{38}$

Individuals with diabetes are found to have lower tissue levels of chromium than nondiabetic controls, with low circulating chromium being associated with the incidence of T2DM. ${ }^{38}$ Clinical trials have shown that chromium supplementation improves glycemic control in patients with diabetes, but this benefit is not found in other trials. ${ }^{14}$ Given limited and controversial data to date, the American Diabetes Association and US FDA have concluded the evidence for the benefit of chromium supplementation in individuals with diabetes as inconclusive. ${ }^{14,38}$

\section{Polyphenols}

Flavonoids

Flavonoids are polyphenols commonly found in fruits, vegetables, legumes, herbs, and tea and have been examined for 
their anti-inflammatory and antioxidant properties. Prospective studies indicate that the intake of flavonoids is inversely associated with CVD incidence or mortality. ${ }^{14}$ Similarly, a systematic review confers favorable benefits of foods rich in flavonoids, including cocoa, chocolate, red wine, grapes, or black tea on CVD parameters (eg, reduced blood pressure and improved endothelial function). ${ }^{14}$

\section{Resveratrol}

Resveratrol is a polyphenol found in a variety of fruits (eg, grapes, berries, and plums) and may have a beneficial effect on cardiovascular health via its antioxidant properties and regulation of nitric oxide concentrations in the body. ${ }^{16}$ Consumption of resveratrol at both 10 and $100 \mathrm{mg} /$ day has been linked to decreased LDL and improved endothelial cell function. ${ }^{21}$ Recently, a favorable effect of trans-resveratrol on glucose homeostasis has been reported at a dose of $150 \mathrm{mg} /$ day over a 1-month intervention period, indicating a potential benefit on insulin sensitivity. ${ }^{19}$ In animal studies, resveratrol has also been shown to decrease fat mass via inhibiting adipocyte differentiation and lipid accumulation and to improve energy efficiency via the regulation of brown fat tissue activity. ${ }^{39}$ However, human data are needed to further explore the influence of resveratrol on weight management.

\section{Isoflavones}

Isoflavones from soy are a class of phytoestrogens that can mimic the effects of estradiol. ${ }^{14}$ Animal studies have shown that soy and phytoestrogens reduce adiposity and improve insulin sensitivity, but human data are limited and inconclusive. ${ }^{14}$

\section{Chlorogenic acid (CGA)}

Also known as 5-O-caffeoylquinic acid, is one of the main polyphenols that is widely distributed in foods including apples, coffee beans, and carrots. This ingredient and its derived compounds have been extensively evaluated both in in vivo and in human studies for its role in the prevention and treatment of MetS and its associated disorders. ${ }^{40}$ As described below in detail, these data have revealed beneficial effects on weight management, T2DM, and hypertension when supplemented with pure CGA or CGA-rich foods/supplements. 1) Consumption of Coffee Slender (45 mg CGA/g) for 12 weeks significantly reduced weight by $5.4 \mathrm{~kg}$ among overweight subjects. ${ }^{40}$ A CGA-rich beverage (329 mg CGA/185 mL) was reported to increase postprandial energy expenditure and fat utilization after 4 weeks of daily consumption among healthy men; ${ }^{40}$ ) a review summarizing findings from five human trials demonstrated a positive impact of CGA-rich foods and supplements or pure CGA on diabetic parameters (eg, glucose absorption). ${ }^{40}$ Consumption of caffeinated (40 mg CGA/g) and decaffeinated coffee (30 mg CGAs/g) decreased glucose-dependent insulinotropic polypeptide, indicating a lowered rate of glucose absorption in the intestine. Coffee Slender (45 mg CGA/g) reduced glucose absorption by $6.9 \%$ among healthy subjects. Similar benefits on plasma glucose and area under the curve were observed for a CGArich extract from decaffeinated green coffee bean $(13.9 \%$ CGA dry weight) among healthy subjects with the highest postprandial glucose levels. Emulin ${ }^{\mathrm{TM}}$ (a patented blend of CGA, myricetin, and quercetin) was reported to lower the glycemic impact of foods among subjects with T2DM; and 3 ) the anti-hypertension properties of pure CGA and CGArich green coffee extract have been investigated in subjects with and without mild hypertension. A health benefit has been reported in these human studies, including a reduction in systolic/diastolic blood pressure and improved endothelial function measured by continuous flow-mediated dilation. ${ }^{40}$

\section{Other compounds}

\section{$\alpha$-Lipoic acid}

The supplementation of $\alpha$-lipoic acid (a naturally occurring antioxidant) has been shown to increase insulin sensitivity among diabetics by $18 \%-20 \%$ and improve acute symptoms and disease progression of diabetic neuropathy. ${ }^{14}$

\section{Benfotiamine}

Benfotiamine is a lipophilic derivative of thiamine (vitamin $\mathrm{B}_{1}$ ) and can increase plasma concentrations of thiamine five times higher than an equivalent dose of thiamine. ${ }^{20}$ In clinical trials, benfotiamine has been demonstrated to prevent vascular endothelial dysfunction and oxidative stress and improve polyneuropathy among diabetic patients. ${ }^{20}$

\section{Fucoxanthin}

Fucoxanthin is a natural carotenoid found in certain types of brown algae, including Undaria pinnatifida (Wakame), Saccharina japonica (Makonbu), and Sargassum fulvellum (Hondawara). ${ }^{41}$ It cannot be converted to vitamin A in the body and is a potent antioxidant. ${ }^{41}$ Fucoxanthin acts by downregulating adipokine secretion that is associated with inflammation in white adipose tissue (WAT) and upregulating glucose transporter 4 that is associated with insulin resistance in skeletal muscle under diabetic conditions. ${ }^{41}$ Animal data indicate that fucoxanthin may reduce excess abdominal fat by inducing the expression of uncoupling protein 1 and thus upregulate thermogenesis in abdominal 
WAT. ${ }^{41}$ In a clinical trial, obese women with a mean body weight of $100 \mathrm{~kg}$ were administered $2.4 \mathrm{mg}$ /day of fucoxanthin for 16 weeks and showed a significant increase in resting energy expenditure and a reduction in body weight, waist circumference, body and liver fat content, and serum triacylglycerol levels. ${ }^{41}$

\section{Policosanol}

Policosanol is an extract from sugarcane wax and has been shown to significantly reduce LDL cholesterol. ${ }^{16}$ It has been reported that policosanol reduced LDL by $17 \%$ among patients who did not reach their LDL target at the maximum dose of statin or with a combination therapy. ${ }^{16}$ In a recent meta-analysis of 11 human RCTs, a specific combination of natural compounds (policosanol, berberine, red yeast rice extract, folic acid, coenzyme Q10, and astaxanthin) was supplemented to examine the benefit on the lipid profile among 3,924 hypercholesterolemic patients. This combination of compounds was reported to significantly reduce all lipid parameters (TC, HDL, LDL, and TG) compared with control. ${ }^{42}$

\section{Stanols}

Stanols, also known as plant sterols, have been shown to decrease LDL cholesterol by reducing the uptake of cholesterol in the gastrointestinal tract; an optimal intake of $\sim 2000$ $\mathrm{mg}$ stanols daily is expected to decrease LDL by $6 \%-20 \%{ }^{16}$

\section{Lifestyle factors}

Although the focus of this review is single nutrients, we highlight a few lifestyle factors that may influence or "program" the development of MetS.

\section{Circadian rhythm}

According to a review of human and animal data, circadian disruption is associated with metabolic disorders..$^{43}$ As illustrated in night-shift workers and those with jetlag, desynchronization between the light-regulated central clock, located in the hypothalamic suprachiasmatic nucleus, and nutrientresponsive peripheral clock can contribute to unfavorable health outcomes (including obesity, T2DM, and CVD). ${ }^{43}$ The influence of dietary components (eg, a high-fat diet and polyphenols) on tissue-specific peripheral clock responses has been investigated using animal, in vitro, and in vivo models, suggesting that feeding is a modulator of the internal circadian clock. ${ }^{43}$ Further human studies are needed to clarify which nutrients can influence and how they can influence the circadian rhythm toward advantageous metabolic outcomes. ${ }^{43}$

\section{Nutrition in early life}

Epidemiological studies have demonstrated that nutrition in early life is associated with MetS, obesity, and diabetes later in adulthood; this is known as the theory of "developmental origins of health and disease" proposed by Barker in the early 1990s. ${ }^{44} 47$ Both maternal undernutrition and overnutrition during pregnancy are correlated with suboptimal infant birth weight (underweight or overweight), altered postnatal growth (eg, rapid catch-up growth among low-birth-weight infants), and an increased risk of adulthood obesity and MetS..$^{44} 46$ Low birth weight is associated with reduced fetal and adulthood muscle mass and consequently increased risks of MetS, T2DM, and CVD later in life. This is in part due to the fact that skeletal muscle is critical to maintaining resting energy expenditure and whole-body insulin sensitivity ${ }^{48}$ In addition, childhood infection and growth restriction may contribute to future metabolic and CVDs, possibly due to caloric deficit and infection-related inflammation. ${ }^{49}$

Although weaning and the introduction of complementary feeding can influence the future health of infants, the relationship between the timing of complementary feeding and the risk of metabolic disorders later in life remains unclear. ${ }^{50}$ However, what is clear is that overconsumption of high-calorie beverages during infancy is associated with childhood obesity. ${ }^{50}$ The addition of salt during infancy may also increase the risk of hypertension later in life, as it may stimulate the development of a preference for salty taste and subsequent high intake of salt. ${ }^{50}$ Although there is evidence showing improved blood pressure among infants who received fish oil supplementation, ${ }^{50}$ there is limited literature about the long-term effects of long-chain omega-3 PUFA during weaning on cardiovascular health. ${ }^{50}$

\section{Conclusion}

Observational studies have generated positive evidence for the beneficial role of numerous nutrients in MetS. The underlying mechanisms include modulation of systemic inflammation, oxidative stress, pancreatic functions, energy absorption/production/utilization, and genetic programming in early life. Although results of some clinical trials are consistent with the findings from observational data, causality remains inconclusive due to either overall contradicting data or an inability to repeat findings or compare findings due to variance in dose, population, and clinical end points.

Both nutrition and health are complex and dynamic systems with a hierarchical nature. Nutrients are essential for health, but they do not work in isolation. When we, as nutrition scientists, design confirmatory intervention 
trials for nutrients and metabolic health, instead of the traditional "single-nutrient" concept, it is worth considering a holistic and interdisciplinary approach to integrate nutrients, lifestyle factors (eg, dietary patterns, physical activity, and circadian rhythm), early risk exposure (eg, in uterus and infancy), and population relevance (eg, healthy, at-risk, or diseased).

\section{Acknowledgment}

An abstract of this paper was presented at "The 2017 Experimental Biology Conference" as a poster presentation. Thereafter, the abstract was published in the FASEB Journal (available from: http://www.fasebj.org/content/31/1 Supplement/789.10.short).

\section{Disclosure}

HJK is an employee of the Nature's Bounty Co. SHM was an employee of the Nature's Bounty Co. when the work was performed. The authors report no other conflicts of interest in this work.

\section{References}

1. McCullough AJ. Epidemiology of the metabolic syndrome in the USA. J Dig Dis. 2011;12(5):333-340.

2. Udenigwe CC, Rouvinen-Watt $\mathrm{K}$. The role of food peptides in lipid metabolism during dyslipidemia and associated health conditions. Int J Mol Sci. 2015;16(5):9303-9313.

3. Ervin RB. Prevalence of metabolic syndrome among adults 20 years of age and over, by sex, age, race and ethnicity, and body mass index: United States, 2003-2006. National Health Statistics Reports; no 13. Hyattsville, MD: National Center for Health Statistics. 2009.

4. Phillips CM. Nutrigenetics and metabolic disease: current status and implications for personalised nutrition. Nutrients. 2013;5(1):32-57.

5. Writing Group Members; Mozzafarian D, Benjamin EJ, et al. Heart Disease And Stroke Statistics-2016 Update: a report from the American Heart Association. Circulation. 2016;133:e38-e360.

6. Centers for Disease Control and Prevention. National Diabetes Statistics Report 2014. Atlanta, GA: Centers for Disease Control and Prevention,US Department of Health and Human Services. 2017.

7. DeVol R, Bedroussian A. Research report: an unhealthy America: the economic burden of chronic disease. Santa Monica CA: Milken Institute. 2017. Available at: http://www.milkeninstitute.org/publications/view/321.

8. Brenseke B, Prater MR, Bahamonde J, Gutierrez JC. Current thoughts on maternal nutrition and fetal programming of the metabolic syndrome. J Pregnancy. 2013;2013:368461.

9. Leidy HJ, Clifton PM, Astrup A, et al. The role of protein in weight loss and maintenance. Am J Clin Nutr. 2015; 101 (Suppl):1320S-9S.

10. Keller U. Dietary proteins in obesity and in diabetes. Int J Vitam Nutr Res. 2011;81(2-3): 125-133.

11. Newsholme P, Cruzat V, Arfuso F, Keane K. Nutrient regulation of insulin secretion and action. J Endocrinol. 2014;221(3):R105-R120.

12. Dugan CE, Fernandez ML. Effects of dairy on metabolic syndrome parameters: a review. Yale J Biol Med. 2014;87(2):135-147.

13. Calton EK, James AP, Pannu PK, Soares MJ. Certain dietary patterns are beneficial for the metabolic syndrome: reviewing the evidence. Nutr Res. 2014;34(7):559-568.

14. Davi G, Santilli F, Patrono C. Nutraceuticals in diabetes and metabolic syndrome. Cardiovasc Ther. 2010;28(4):216-226.
15. Roche HM. Fatty acids and the metabolic syndrome. Proc Nutr Soc. 2005;64(1):23-29.

16. Whayne TF Jr, Maulik N. Nutrition and the healthy heart with an exercise boost. Can J Physiol Pharmacol. 2012;90(8):967-976.

17. Malik P, Popkin BM, Bray GA, Després JP, Willett WC, Hu FB. Sugar-sweetened beverages and risk of metabolic syndrome and type 2 diabetes: a meta-analysis. Diabetes Care. 2010;33(11):2477-2483.

18. Renwick AG, Molinary SV. Sweet-taste receptors, low-energy sweeteners, glucose absorption and insulin release. BrJNutr. 2010;104:1415-1420.

19. Avignon A, Hokayem M, Bisbal C, Lambert K. Dietary antioxidants: do they have a role to play in the ongoing fight against abnormal glucose metabolism? Nutrition. 2012;28(7-8):715-721.

20. Dakshinamurti K. Vitamins and their derivatives in the prevention and treatment of metabolic syndrome diseases (diabetes). Can J Physiol Pharmacol. 2015;93(5):355-362.

21. Xu YJ, Tappia PS, Neki NS, Dhalla NS. Prevention of diabetes-induced cardiovascular complications upon treatment with antioxidants. Heart Fail Rev. 2014;19(1):113-121.

22. Makariou S, Liberopoulos EN, Elisaf M, Challa A. Novel roles of vitamin D in disease: what is new in 2011? Eur J Intern Med. 2011;22(4):355-362.

23. Renzaho AM, Halliday JA, Nowson C. Vitamin D, obesity, and obesityrelated chronic disease among ethnic minorities: a systematic review. Nutrition. 2011;27(9):868-879.

24. Cosenso-Martin LN, Vilela-Martin JF. Is there an association between vitamin D and hypertension? Recent Pat Cardiovasc Drug Discov. 2011;6(2):140-147.

25. Penckofer S, Kouba J, Wallis DE, Emanuele MA. Vitamin D and diabetes: let the sunshine in. Diabetes Educ. 2008;34(6):939-940, 942, 944 passim.

26. Mozos I, Marginean O. Links between vitamin D deficiency and cardiovascular diseases. Biomed Res Int. 2015;2015:109275.

27. Khan H, Kunutsor S, Franco OH, Chowdhury R. Vitamin D, type 2 diabetes and other metabolic outcomes: a systematic review and metaanalysis of prospective studies. Proc Nutr Soc. 2013;72(1):89-97.

28. Pittas AG, Lau J, Hu FB, Dawson-Hughes B. The role of vitamin D and calcium in type 2 diabetes. A systematic review and meta-analysis. J Clin Endocrinol Metab. 2007;92(6):2017-2029.

29. Ju SY, Jeong HS, Kim DH. Blood vitamin D status and metabolic syndrome in the general adult population: a dose-response meta-analysis. $J$ Clin Endocrinol Metab. 2014;99(3):1053-1063.

30. Barengolts E. Vitamin D role and use in prediabetes. Endocr Pract. 2010;16(3):476-485.

31. Garbossa SG, Folli F. Vitamin D, sub-inflammation and insulin resistance: a window on a potential role for the interaction between bone and glucose metabolism. Rev Endocr Metab Disord 2017;18:243-258.

32. da Silva RP, Kelly KB, Al Rajabi A, Jacobs RL. Novel insights on interactions between folate and lipid metabolism. Biofactors. 2014;40(3):277-283.

33. Guerrera MP, Volpe SL, Mao JJ. Therapeutic uses of magnesium. Am Fam Physician. 2009;80(2):157-162.

34. Zhang X, Li Y, Del Gobbo LC, et al. Effects of magnesium supplementation on blood pressure-a meta-analysis of randomized double-blind placebo-controlled trials. Hypertension. 2016;68(2):324-333.

35. Floege J. Magnesium in CKD: more than a calcification inhibitor? J Nephrol. 2015;28(3):269-277.

36. Volpe SL. Magnesium, the metabolic syndrome, insulin resistance, and type 2 diabetes mellitus. Crit Rev Food Sci Nutr. 2008;48(3):293-300.

37. He K, Song Y, Belin RJ, Chen Y. Magnesium intake and the metabolic syndrome: epidemiologic evidence to date. J Cardiometab Syndr. 2006;1(5): 351-355.

38. Hummel M, Standl E, Schnell O. Chromium in metabolic and cardiovascular disease. Horm Metab Res. 2007;39(10):743-751.

39. AzharY, Parmar A, Miller CN, Samuels JS, Rayalam S. Phytochemicals as novel agents for the induction of browning in white adipose tissue. Nutr Metab (Lond). 2016;13:89.

40. Santana-Galvez J, Cisneros-Zevallos L, Jacobo-Velazquez DA. Chlorogenic acid: recent advances on its dual role as a food additive and a nutraceutical against metabolic syndrome. Molecules. 2017;22(3):pii:E358. 
41. Maeda H. Nutraceutical effects of fucoxanthin for obesity and diabetes therapy: a review. J Oleo Sci. 2015;64(2):125-132.

42. Millan J, Cicero AFG, Torres F, Anguera A. Effects of a nutraceutical combination containing berberine (BRB), policosanol, and red yeast rice (RYR), on lipid profile in hypercholesterolemic patients: a metaanalysis of randomized controlled trials. Clin Investig Arterioscler. 2016;28(4):178-187.

43. Ribas-Latre A, Eckel-Mahan K. Interdependence of nutrient metabolism and the circadian clock system: importance for metabolic health. $M o l$ Metab. 2016;5(3):133-152.

44. Desai M, Jellyman JK, Ross MG. Epigenomics, gestational programming and risk of metabolic syndrome. Int JObes (Lond). 2015;39(4):633-641.

45. Tarrade A, Panchenko P, Junien C, Gabory A. Placental contribution to nutritional programming of health and diseases: epigenetics and sexual dimorphism. J Exp Biol. 2015;218(Pt 1):50-58.
46. Brenseke B, Prater MR, Bahamonde J, Gutierrez JC. Current thoughts on maternal nutrition and fetal programming of the metabolic syndrome. J Pregnancy. 2013;2013:368461.

47. Knip M, Akerblom HK. Early nutrition and later diabetes risk. Adv Exp Med Biol. 2005;569:142-150.

48. Brown LD. Endocrine regulation of fetal skeletal muscle growth: impact on future metabolic health. $J$ Endocrinol. 2014;221(2):R13-R29.

49. DeBoer MD, Lima AA, Oría RB, et al. Early childhood growth failure and the developmental origins of adult disease: do enteric infections and malnutrition increase risk for the metabolic syndrome? Nutr Rev. 2012;70(11):642-653.

50. Alvisi P, Brusa S, Alboresi S, et al. Recommendations on complementary feeding for healthy, full-term infants. Ital J Pediatr. 2015;41:36. 


\section{Supplementary material}

Table SI Summary of reviews and meta-analyses (2005-2017)

\begin{tabular}{|c|c|c|c|c|}
\hline Reference & $\begin{array}{l}\text { Metabolic } \\
\text { syndrome } \\
\text { parameters }\end{array}$ & $\begin{array}{l}\text { Nutrients/factors } \\
\text { reviewed }\end{array}$ & Main findings & Comments \\
\hline 25 & Diabetes & Vitamin D & $\begin{array}{l}\text { Human clinical trials produced controversial } \\
\text { data on the effects of vitamin } D \\
\text { supplementation on diabetic parameters both in } \\
\text { healthy and diabetic subjects }\end{array}$ & $\begin{array}{l}\text { A review of observational studies } \\
\text { and clinical trials }\end{array}$ \\
\hline 33 & $\begin{array}{l}\text { Obesity/T2DM/ } \\
\text { hypertension }\end{array}$ & CGA & $\begin{array}{l}\text { Human studies have revealed positive effects of } \\
\text { pure CGA or CGA-rich foods/supplements on } \\
\text { obesity/T2DM/hypertension. Human data are } \\
\text { needed to evaluate the effects on dyslipidemia }\end{array}$ & $\begin{array}{l}\text { Most studies are done with } \\
\text { CGA-rich coffee. More trials are } \\
\text { needed for pure CGA }\end{array}$ \\
\hline 35 & Dyslipidemia & $\begin{array}{l}\text { AP, a commercial dietary } \\
\text { supplement combining } \\
\text { policosanol, berberine, } \\
\text { red yeast rice extract, } \\
\text { folic acid, coenzyme } \\
\text { QI0, and astaxanthin }\end{array}$ & $\begin{array}{l}\text { AP significantly improves all lipid parameters } \\
\text { (total cholesterol, LDL, HDL, and TG) }\end{array}$ & $\begin{array}{l}\text { Meta-analysis of II RCTs among } \\
\text { hypercholesterolemic patients } \\
\text { (pre } 2015 \text { literature). Between- } \\
\text { study heterogeneity is substantial }\end{array}$ \\
\hline 36 & MetS & Circadian rhythm & $\begin{array}{l}\text { Circadian disruption is associated with } \\
\text { metabolic disorders. Feeding is a modulator } \\
\text { of the internal circadian clock. Further studies } \\
\text { among humans are needed }\end{array}$ & $\begin{array}{l}\text { Nutrients and circadian clocks } \\
\text { are from animal, in vitro, or in } \\
\text { vivo data }\end{array}$ \\
\hline 28 & Hypertension & Magnesium & $\begin{array}{l}\text { Magnesium supplementation at a median dose } \\
\text { of } 368 \mathrm{mg} / \text { day for a median duration of } 3 \\
\text { months reduces systolic and diastolic blood } \\
\text { pressure by } 2 \text { and } 1.78 \mathrm{mmHg} \text {, respectively }\end{array}$ & $\begin{array}{l}\text { Meta-analysis of RCTs among } \\
\text { adults (literature up to } \\
\text { February I, 20I6); Benefits are } \\
\text { accompanied by elevated levels of } \\
\text { serum magnesium }\end{array}$ \\
\hline 43 & $\begin{array}{l}\text { Obesity/ } \\
\text { hypertension }\end{array}$ & $\begin{array}{l}\text { Complementary feeding: } \\
\text { EPL, salt, and LCPUFA }\end{array}$ & $\begin{array}{l}\text { The correlation between the timing of } \\
\text { complementary feeding and MetS in later life } \\
\text { remains unclear }\end{array}$ & $\begin{array}{l}\text { Limited evidence on early } \\
\text { introduction of EPL, salt, } \\
\text { LCPUFA, and metabolic health } \\
\text { later in life }\end{array}$ \\
\hline 14 & T2DM & $\begin{array}{l}\text { Vitamin } A \text {, retinol- } \\
\text { binding protein } 4 \text {, } \\
\text { vitamin } D \text {, biotin, } \\
\text { and benfotiamine (a } \\
\text { derivative of thiamine) }\end{array}$ & $\begin{array}{l}\text { Vitamins and their derivatives have the potential } \\
\text { as an effective adjunct prevention of T2DM }\end{array}$ & $\begin{array}{l}\text { Vitamin } A \text { and biotin: in vitro or } \\
\text { animal data only }\end{array}$ \\
\hline 37 & MetS & $\begin{array}{l}\text { Under- and } \\
\text { overnutrition in utero }\end{array}$ & $\begin{array}{l}\text { A U-shaped relationship between birth weight } \\
\text { and adulthood metabolic diseases: babies with } \\
\text { low or high birth weight have increased risks of } \\
\text { MetS later in life }\end{array}$ & $\begin{array}{l}\text { Epigenomic mechanisms are } \\
\text { mainly based on animal data }\end{array}$ \\
\hline 29 & $\begin{array}{l}\text { Hypertension/ } \\
\text { T2DM/CVD }\end{array}$ & Magnesium & $\begin{array}{l}\text { Magnesium status (intake, serum levels, or } \\
\text { urinary secretion) is inversely linked to the risk } \\
\text { of hypertension/T2DM/CVD in observational } \\
\text { studies }\end{array}$ & $\begin{array}{l}\text { Causality needs to be confirmed } \\
\text { in RCTs }\end{array}$ \\
\hline 3 & Obesity & Protein & $\begin{array}{l}\text { High-protein diets ( } 1.2-1.6 \mathrm{~g} \text { protein } / \mathrm{kg} / \\
\text { day) improve weight management and some } \\
\text { metabolic indicators through increased } \\
\text { thermogenesis and satiety after the } \\
\text { consumption }\end{array}$ & $\begin{array}{l}\text { Short-term }(<1 \text { year }) \text { evidence is } \\
\text { strong; long-term feeding trials } \\
(\geq 1 \text { year }) \text { are less consistent }\end{array}$ \\
\hline 34 & Obesity & $\begin{array}{l}\text { Fucoxanthin, a natural } \\
\text { carotenoid from brown } \\
\text { algae }\end{array}$ & $\begin{array}{l}\text { Fucoxanthin in algae has a unique anti-obesity } \\
\text { effect by upregulating thermogenesis in human } \\
\text { white fat tissues }\end{array}$ & $\begin{array}{l}\text { The anti-diabetic properties of } \\
\text { fucoxanthin: animal and in vitro } \\
\text { data only }\end{array}$ \\
\hline 20 & $\begin{array}{l}\text { Hypertension/ } \\
\text { T2DM/CVD }\end{array}$ & Vitamin D & $\begin{array}{l}\text { Low vitamin } D \text { status is linked to increased } \\
\text { prevalence or risks of hypertension, T2DM, } \\
\text { and CVD }\end{array}$ & $\begin{array}{l}\text { Benefits of vitamin D } \\
\text { supplementation on } \\
\text { cardiovascular outcomes have not } \\
\text { been confirmed }\end{array}$ \\
\hline
\end{tabular}


Table SI (Continued)

\begin{tabular}{|c|c|c|c|c|}
\hline Reference & $\begin{array}{l}\text { Metabolic } \\
\text { syndrome } \\
\text { parameters }\end{array}$ & $\begin{array}{l}\text { Nutrients/factors } \\
\text { reviewed }\end{array}$ & Main findings & Comments \\
\hline 38 & MetS & In utero nutrition & $\begin{array}{l}\text { Maternal nutrition during peri-conception, } \\
\text { gestation, and lactation periods predisposes } \\
\text { babies to adult-onset diseases }\end{array}$ & Known as "DOHaD" \\
\hline I & Dyslipidemia & $\begin{array}{l}\text { Peptides from dietary } \\
\text { proteins (ie, soybean and } \\
\text { milk) or synthetic }\end{array}$ & $\begin{array}{l}\text { A human clinical trial shows beneficial effects of } \\
\text { lupin protein on lowering plasma lipids }\end{array}$ & $\begin{array}{l}\text { Evidence is mainly based on } \\
\text { animal, in vitro, or cell culture } \\
\text { data }\end{array}$ \\
\hline 41 & $\begin{array}{l}\text { MetS/T2DM/ } \\
\text { CVD }\end{array}$ & $\begin{array}{l}\text { Low birth weight/ } \\
\text { reduced fetal muscle } \\
\text { mass }\end{array}$ & $\begin{array}{l}\text { Compelling associations between low birth } \\
\text { weight/reduced muscle mass and MetS/T2DM/ } \\
\text { CVD later in life }\end{array}$ & Related to the $\mathrm{DOHaD}$ theory \\
\hline 7 & MetS & $\begin{array}{l}\text { Dietary components } \\
\text { consumed as part of } \\
\text { specific diets }\end{array}$ & $\begin{array}{l}\text { Beneficial roles of unsaturated fatty acids } \\
\text { (MUFA, omega-3/omega-6 PUFA, EPA, DHA, } \\
\text { and ALA) on metabolic parameters; adverse } \\
\text { influences of saturated and trans fatty acids }\end{array}$ & $\begin{array}{l}\text { Systematic review of prospective } \\
\text { and RCT studies: } 2000-2012\end{array}$ \\
\hline 26 & Obesity/CVD & Folate & $\begin{array}{l}\text { Correlation between low folate status and } \\
\text { adiposity/CVD is observed in epidemiological } \\
\text { studies }\end{array}$ & $\begin{array}{l}\text { Causality and efficacy need to } \\
\text { be confirmed in well-designed } \\
\text { intervention trials }\end{array}$ \\
\hline 6 & MetS & Dairy & $\begin{array}{l}\text { Epidemiological and clinical studies suggest an } \\
\text { inverse relationship between dairy consumption } \\
\text { and MetS parameters }\end{array}$ & $\begin{array}{l}2-3 \text { servings of dairy per day is } \\
\text { recommended }\end{array}$ \\
\hline 23 & MetS & Vitamin D & $\begin{array}{l}\text { An inverse association between blood } 25(\mathrm{OH}) \\
D \text { levels and MetS risks is observed among the } \\
\text { meta-analysis of cross-sectional data }(n=16) \text {, } \\
\text { but not in cohort or nest case-control studies } \\
(n=2)\end{array}$ & $\begin{array}{l}\text { Cross-sectional data: pooled } \\
\text { OR per } 25 \mathrm{nmol} / \mathrm{L} \text { increment in } \\
\text { 25(OH)D: OR }=0.87 ; 95 \% \mathrm{Cl}: \\
0.83-0.92 ; \text { high heterogeneity: } \\
\mathrm{I}^{2}=85 \%\end{array}$ \\
\hline 5 & T2DM & $\begin{array}{l}\text { Branched-chain amino } \\
\text { acids; non-esterified } \\
\text { fatty acids }\end{array}$ & $\begin{array}{l}\text { Nutrient effects on pancreatic functions are } \\
\text { complex at the metabolic level; much is yet to } \\
\text { be understood }\end{array}$ & $\begin{array}{l}\text { Focus on the mechanism; few } \\
\text { human data }\end{array}$ \\
\hline 15 & MetS/CVD & $\begin{array}{l}\text { Antioxidants (vitamins } C \\
\text { and } E \text {, resveratrol) }\end{array}$ & $\begin{array}{l}\text { Observational data, not RCTs, support the } \\
\text { benefits of a minimum 2-year supplementation } \\
\text { of antioxidant vitamins ( } C \text { and } E \text { ) on reduced } \\
\text { incidence of CVD. Resveratrol is shown in } \\
\text { two clinical trials to improve endothelial cell } \\
\text { function and LDL profiles }\end{array}$ & $\begin{array}{l}\text { A natural supplement containing } \\
\text { resveratrol and antioxidant } \\
\text { vitamins may be promising to } \\
\text { manage CVD burdens }\end{array}$ \\
\hline 39 & MetS & $\begin{array}{l}\text { Nutrition during } \\
\text { pregnancy }\end{array}$ & $\begin{array}{l}\text { Maternal diet during pregnancy can influence } \\
\text { the short- and long-term health of offspring } \\
\text { including programming of the MetS }\end{array}$ & Related to the $\mathrm{DOHaD}$ theory \\
\hline 21 & MetS/T2DM & $\begin{array}{l}\text { Baseline vitamin } D \text { status } \\
\text { measured as blood } \\
25(\mathrm{OH}) \mathrm{D} \text { and dietary } \\
\text { intakes }\end{array}$ & $\begin{array}{l}\text { Vitamin } D \text { status at baseline is inversely } \\
\text { associated with risks of MetS and T2DM. Top } \\
\text { versus bottom thirds of baseline vitamin D: for } \\
\text { MetS: } R R=0.86 ; 95 \% \mathrm{Cl}=0.80-0.92 \text {. For T2DM: } \\
R R=0.8 \mathrm{I} ; 95 \% \mathrm{Cl}=0.7 \mathrm{I}-0.92\end{array}$ & $\begin{array}{l}\text { A meta-analysis of I } 8 \text { prospective } \\
\text { studies (literature up to August } \\
\text { 20I2); results need to be } \\
\text { confirmed by intervention trials }\end{array}$ \\
\hline 2 & MetS & Dietary fats & $\begin{array}{l}\text { High saturated fatty acid diets have detrimental } \\
\text { effects on metabolic health; diets rich in MUFA } \\
\text { are advantageous for metabolic parameters. } \\
\text { Optimal dietary fat composition for metabolic } \\
\text { health is unknown }\end{array}$ & $\begin{array}{l}\text { Epidemiological data on anti- } \\
\text { diabetic benefits of omega- } 3 \\
\text { LCPUFA are controversial }\end{array}$ \\
\hline 13 & $\begin{array}{l}\text { Glucose } \\
\text { metabolism }\end{array}$ & Dietary antioxidants & $\begin{array}{l}\text { The involvement of oxidative stress in insulin } \\
\text { resistance is clear; intervention studies assessing } \\
\text { antioxidants on glucose metabolism are rare } \\
\text { and results are not consistent }\end{array}$ & $\begin{array}{l}\text { The ideal antioxidant supplements } \\
\text { may be one that can reproduce } \\
\text { the natural combination in plant } \\
\text { foods }\end{array}$ \\
\hline 42 & MetS & $\begin{array}{l}\text { Childhood infection and } \\
\text { growth failure }\end{array}$ & $\begin{array}{l}\text { Childhood infection and growth restriction } \\
\text { may be related to MetS in adulthood. Etiology } \\
\text { is unclear }\end{array}$ & Related to the $\mathrm{DOHaD}$ theory \\
\hline
\end{tabular}


Table SI (Continued)

\begin{tabular}{|c|c|c|c|c|}
\hline Reference & $\begin{array}{l}\text { Metabolic } \\
\text { syndrome } \\
\text { parameters }\end{array}$ & $\begin{array}{l}\text { Nutrients/factors } \\
\text { reviewed }\end{array}$ & Main findings & Comments \\
\hline 10 & CVD & $\begin{array}{l}\text { Dietary components, } \\
\text { antioxidants, vitamin D, } \\
\text { alternative supplements } \\
\text { (resveratrol, policosanol, } \\
\text { red yeast rice, stanols), } \\
\text { and exercise }\end{array}$ & $\begin{array}{l}\text { Basic nutrition together with exercise plays a } \\
\text { critical role in cardiovascular health }\end{array}$ & $\begin{array}{l}\text { Alternative supplements are } \\
\text { promising, but need more data }\end{array}$ \\
\hline 18 & Hypertension & Vitamin D & $\begin{array}{l}\text { Observational data support a protective role } \\
\text { of vitamin } D \text { against hypertension, but } R C T s \\
\text { do not support the benefits of vitamin D } \\
\text { supplementation }\end{array}$ & $\begin{array}{l}\text { More randomized trials are } \\
\text { necessary to confirm the benefits } \\
\text { of vitamin } D \text { and hypertension }\end{array}$ \\
\hline 4 & Obesity & Proteins & $\begin{array}{l}\text { Dietary proteins may help weight management } \\
\text { through increasing thermogenesis and satiety. } \\
\text { Long-term benefits need to be further studied }\end{array}$ & $\begin{array}{l}\text { Caution for high-protein diets: } \\
\text { risks of renal damage especially in } \\
\text { diabetics }\end{array}$ \\
\hline 16 & $\begin{array}{l}\text { MetS/ } \\
\text { hypertension/ } \\
\text { CVD }\end{array}$ & Vitamin D & $\begin{array}{l}\text { Observational data, not intervention trials, are } \\
\text { supportive of beneficial roles of vitamin D on } \\
\text { metabolic disorders }\end{array}$ & $\begin{array}{l}\text { Future clinical trials are needed to } \\
\text { confirm the casual relationship }\end{array}$ \\
\hline 17 & $\begin{array}{l}\text { Obesity/T2DM/ } \\
\text { CVD }\end{array}$ & $\begin{array}{l}\text { Vitamin D insufficiency: } \\
25(\mathrm{OH}) \mathrm{D}<50 \mathrm{nmol} / \mathrm{L}\end{array}$ & $\begin{array}{l}\text { Ethnic minorities have higher prevalence of } \\
\text { vitamin } D \text { insufficiency than white counterparts. } \\
\text { Observational data support links between } \\
\text { vitamin } D \text { deficiency and obesity-related } \\
\text { chronic diseases }\end{array}$ & $\begin{array}{l}\text { Systematic review of } \\
\text { observational data in minority } \\
\text { groups (narrative synthesis) }\end{array}$ \\
\hline 12 & Insulin resistance & $\begin{array}{l}\text { Low-energy sweeteners } \\
\text { (aspartame, saccharin, } \\
\text { sucrose, acesulfame-K, } \\
\text { cyclamate, saccharin, } \\
\text { sucralose, stevioside, } \\
\text { and rebaudioside-A) }\end{array}$ & $\begin{array}{l}\text { Low-energy sweeteners are not associated with } \\
\text { unwanted effects on appetite, glycemic control, } \\
\text { or blood pressure }\end{array}$ & $\begin{array}{l}\text { Based on in vivo human and } \\
\text { animal data }\end{array}$ \\
\hline 24 & Prediabetes & Vitamin D & $\begin{array}{l}\text { Observational data are supportive. Intervention } \\
\text { trials indicate no benefits of vitamin } D \\
\text { supplementation among people with adequate } \\
\text { vitamin D status and normal glucose tolerance. } \\
\text { A few short-term trials with a small sample size } \\
\text { indicate possible benefits in prediabetes }\end{array}$ & $\begin{array}{l}\text { Systematic review of literature } \\
\text { from January } 1969 \text { to July } 2009 ; \\
\text { well-designed trials considering } \\
\text { relevant confounders (ie, vitamin } \\
\text { D status and glucose metabolism) } \\
\text { are needed to confirm the } \\
\text { efficacy }\end{array}$ \\
\hline 8 & MetS/T2DM & $\begin{array}{l}\text { Antioxidants (vitamins, } \\
\text { polyphenols, and ALA), } \\
\text { minerals (chromium and } \\
\text { magnesium), omega } 3 \text {, } \\
\text { soy isoflavones, and fiber }\end{array}$ & $\begin{array}{l}\text { An inverse association between antioxidants } \\
\text { and CVD prevention is strong in observational } \\
\text { studies, but this is not supported by currently } \\
\text { available large clinical trials }\end{array}$ & $\begin{array}{l}\text { More clinical data involving } \\
\text { people with high oxidant stress or } \\
\text { depletion of natural antioxidant } \\
\text { defense systems are needed to } \\
\text { confirm the causality }\end{array}$ \\
\hline II & $\begin{array}{l}\text { MetS/ } \\
\text { hypertension/ } \\
\text { T2DM/CVD }\end{array}$ & SSBs & $\begin{array}{l}\text { Clear evidence on SSB consumption and } \\
\text { increased risks for metabolic disorders }\end{array}$ & $\begin{array}{l}\text { Meta-analysis of prospective } \\
\text { studies }\end{array}$ \\
\hline 27 & MetS & Magnesium & $\begin{array}{l}\text { Possible evidence but further investigation is } \\
\text { needed }\end{array}$ & $\begin{array}{l}\text { Use with caution in the presence } \\
\text { of kidney dysfunction and } \\
\text { medications }\end{array}$ \\
\hline 19 & $\begin{array}{l}\text { MetS/diabetes/ } \\
\text { CVD }\end{array}$ & Vitamin D & Positive evidence from epidemiological data & $\begin{array}{l}\text { Similar information to Pittas } \\
\text { et } \mathrm{a}^{22}\end{array}$ \\
\hline 30 & MetS/T2DM & Magnesium & $\begin{array}{l}\text { Positive evidence on magnesium and MetS/ } \\
\text { T2DM/insulin resistance from observational } \\
\text { studies (cross-sectional and prospective) and a } \\
\text { few RCTs }\end{array}$ & $\begin{array}{l}\text { Literature review: } 2000-2008 \text {; } \\
\text { more prospective or RCTs are } \\
\text { needed to clarify the benefits }\end{array}$ \\
\hline 32 & MetS/T2DM & Chromium & $\begin{array}{l}\text { Supportive evidence but not conclusive } \\
\text { according to FDA/American Diabetes } \\
\text { Association positions }\end{array}$ & $\begin{array}{l}\text { Literature review: } 1996-2006 \\
\text { suggests future studies on certain } \\
\text { forms (ie, chromium picolinate) } \\
\text { and doses (ie, } \geq 200 \mu g / \text { day) }\end{array}$ \\
\hline
\end{tabular}


Table SI (Continued)

\begin{tabular}{|c|c|c|c|c|}
\hline Reference & $\begin{array}{l}\text { Metabolic } \\
\text { syndrome } \\
\text { parameters }\end{array}$ & $\begin{array}{l}\text { Nutrients/factors } \\
\text { reviewed }\end{array}$ & Main findings & Comments \\
\hline 22 & MetS/T2DM & Vitamin D/calcium & $\begin{array}{l}\text { Observational data support an inverse } \\
\text { association of vitamin } \mathrm{D} \text { and calcium with MetS/ } \\
\text { T2DM (prevalence or incidence). Intervention } \\
\text { data are limited }\end{array}$ & $\begin{array}{l}\text { Systematic review with meta- } \\
\text { analysis: observational and clinical } \\
\text { data up to January } 2007\end{array}$ \\
\hline 31 & MetS & Magnesium & $\begin{array}{l}\text { Magnesium intakes are inversely related to } \\
\text { the prevalence and incidence of MetS and its } \\
\text { components }\end{array}$ & $\begin{array}{l}\text { Evidence from a few cross- } \\
\text { sectional and prospective studies }\end{array}$ \\
\hline 40 & Diabetes & Early nutrition & $\begin{array}{l}\text { Pool fetal nutrition, early feeding, high-nutrient } \\
\text { diet, and rapid growth in infancy may adversely } \\
\text { impact the metabolic health later in life }\end{array}$ & $\begin{array}{l}\text { Relevant to the theory of } \\
\mathrm{DOHaD}\end{array}$ \\
\hline 9 & MetS & Fatty acids & $\begin{array}{l}\text { Replacement of dietary saturated fats with } \\
\text { unsaturated fatty acids may benefit metabolic } \\
\text { health. Evidence on benefits of individual fatty } \\
\text { acids is not conclusive }\end{array}$ & $\begin{array}{l}\text { Diet-gene interactions need to b } \\
\text { considered when assessing dietar) } \\
\text { responsiveness }\end{array}$ \\
\hline $44^{a}$ & $\begin{array}{l}\text { Inflammation } \\
\text { (CRP \& IL-6) }\end{array}$ & $\begin{array}{l}\text { Vitamin-mineral } \\
\text { supplementation }\end{array}$ & $\begin{array}{l}\text { There are no differences in CRP and IL- } 6 \\
\text { between subjects with vitamin-mineral } \\
\text { supplementation and placebo controls }\end{array}$ & $\begin{array}{l}\text { A meta-analysis of } 18 \text { trials } \\
\text { ( } 1,747 \text { participants) for CRP and } \\
9 \text { trials ( }(1,037 \text { subjects) for IL-6 } \\
\text { (literature up to May 2009) }\end{array}$ \\
\hline
\end{tabular}

Notes: $\mathrm{n}=44$. ${ }^{\text {SSun }} \mathrm{CH}$, Li Y, Zhang YB, Wang F, Zhou XL, Wang F. The effect of vitamin-mineral supplementation on CRP and IL-6: a systemic review and meta-analysis of randomised controlled trials. Nutr Metab Cardiovasc Dis. 20II;2I (8):576-583. (Not referenced in the paper.)

Abbreviations: 25(OH)D, 25-hydroxyvitamin D; ALA, alpha-linoleic acid; AP, Armolipid Plus; CGA, chlorogenic acid; CRP, C-reactive protein; CVD, cardiovascular disease; DHA, docosahexaenoic acid; DOHaD, developmental origins of health and diseases; EPA, eicosapentaenoic acid; EPL, energy-providing liquids; FDA, Food and Drug Administration; HDL, high-density lipoprotein; IL-6, interleukin-6; LDL, low-density lipoprotein; LCPUFA, long-chain polyunsaturated fatty acids; MetS, metabolic syndrome; MUFA, monounsaturated fatty acids; OR, odds ratio; PUFA, polyunsaturated fatty acids; RCTs, randomized clinical trials; RR, relative risk; SSBs, sugar-sweetened beverages; T2DM, type 2 diabetes mellitus; TC, total cholesterol; TG, triglycerides.

\section{References}

1. Udenigwe CC, Rouvinen-Watt K. The role of food peptides in lipid metabolism during dyslipidemia and associated health conditions. Int J Mol Sci 2015; 16(5):9303-9313.

2. Phillips, CM. Nutrigenetics and metabolic disease: current status and implications for personalised nutrition. Nutrients 2013; 5(1):32-57.

3. Leidy HJ, Clifton PM, Astrup A, Wycherley TP, Westerterp-Plantenga MS, Luscombe-Marsh ND, Woods SC, Mattes RD. The role of protein in weight loss and maintenance. Am J Clin Nutrition 2015; 101 (Suppl):1320S-9S.

4. Keller U. Dietary proteins in obesity and in diabetes. Int J Vitam Nutr Res 2011; 81(2-3):125-133.

5. Newsholme P, Cruzat V, Arfuso F, Keane K. Nutrient regulation of insulin secretion and action. $J$ Endocrinol 2014; 221(3): R105-120.

6. Dugan CE, Fernandez ML. Effects of dairy on metabolic syndrome parameters: a review. Yale J Biol Med 2014; 87(2):135-147.

7. Calton EK, James AP, Pannu PK, Soares MJ. Certain dietary patterns are beneficial for the metabolic syndrome: reviewing the evidence. Nutr Res 2014; 34(7):559-568.

8. Davi G, Santilli F, Patrono C. Nutraceuticals in diabetes and metabolic syndrome. Cardiovasc Ther 2010; 28(4):216-226.

9. Roche HM. Fatty acids and the metabolic syndrome. Proc Nutr Soc 2005; 64(1):23-29.

10. Whayne TF Jr., Maulik N. Nutrition and the healthy heart with an exercise boost. Can J Physiol Pharmacol 2012; 90(8):967-976.

11. Malik P, Popkin BM, Bray GA, Després JP, Willett WC, Hu FB. Sugar-sweetened beverages and risk of metabolic syndrome and type 2 diabetes: a meta-analysis. Diabetes Care 2010; 33(11):2477-83.

12. Renwick AG, Molinary SV. Sweet-taste receptors, low-energy sweeteners, glucose absorption and insulin release. British Journal of Nutrition 2010; 104:1415-1420
13. Avignon A, Hokayem M, Bisbal C, Lambert K. Dietary antioxidants: Do they have a role to play in the ongoing fight against abnormal glucose metabolism? Nutrition 2012; 28(7-8):715-721.

14. Dakshinamurti, K.Vitamins and their derivatives in the prevention and treatment of metabolic syndrome diseases (diabetes). Can J Physiol Pharmacol 2015; 93(5):355-362.

15. Xu YJ, Tappia PS, Neki NS, Dhalla NS. Prevention of diabetes-induced cardiovascular complications upon treatment with antioxidants. Heart Fail Rev 2014; 19(1):113-121.

16. Makariou S, Liberopoulos EN, Elisaf M, Challa A. Novel roles of vitamin D in disease: what is new in 2011? Eur J Intern Med 2011;22(4):355-362.

17. Renzaho AM, Halliday JA, Nowson C. Vitamin D, obesity, and obesityrelated chronic disease among ethnic minorities: a systematic review. Nutrition 2011; 27(9):868-879.

18. Cosenso-Martin LN, Vilela-Martin JF. Is there an association between vitamin D and hypertension? Recent Pat Cardiovasc Drug Discov 2011; 6(2):140-147.

19. Penckofer S, Kouba J, Wallis DE, Emanuele MA. Vitamin D and diabetes: let the sunshine in. Diabetes Educ 2008; 34(6):939-940, 942, 944 passim.

20. Mozos I, Marginean O. Links between Vitamin D Deficiency and Cardiovascular Diseases. Biomed Res Int 2015:109275.

21. Khan H, Kunutsor S, Franco OH, Chowdhury R. Vitamin D, type 2 diabetes and other metabolic outcomes: a systematic review and metaanalysis of prospective studies. Proc Nutr Soc 2013; 72(1):89-97.

22. Pittas AG, Lau J, Hu FB, Dawson-Hughes B. The role of vitamin D and calcium in type 2 diabetes. A systematic review and meta-analysis. $J$ Clin Endocrinol Metab 2007; 92(6):2017-2029.

23. Ju SY, Jeong HS, Kim DH. Blood vitamin D status and metabolic syndrome in the general adult population: a dose-response meta-analysis. $J$ Clin Endocrinol Metab 2014; 99(3):1053-1063.

24. Barengolts E. Vitamin D role and use in prediabetes. Endocr Pract $2010 ; 16(3): 476-485$ 
25. Garbossa SG, Folli F. Vitamin D, sub-inflammation and insulin resistance: a window on a potential role for the interaction between bone and glucose metabolism. Rev Endocr Metab Disord 2017;18:243-258.

26. da Silva RP, Kelly KB, Al Rajabi A, Jacobs RL. Novel insights on interactions between folate and lipid metabolism. Biofactors 2014; 40(3):277-283.

27. Guerrera MP, Volpe SL, Mao JJ. Therapeutic uses of magnesium. Am Fam Physician 2009. 80(2):157-162.

28. Zhang X, Li Y, Del Gobbo LC, Rosanoff A, Wang J, Zhang W, Song Y. Effects of magnesium supplementation on blood pressure-a metaanalysis of randomized double-blind placebo-controlled trials. Hypertension 2016; 68.

29. Floege J. Magnesium in CKD: more than a calcification inhibitor? $J$ Nephrol 2015; 28(3):269-277.

30. Volpe SL. Magnesium, the metabolic syndrome, insulin resistance, and type 2 diabetes mellitus. Crit Rev Food Sci Nutr 2008; 48(3):293-300.

31. He K, Song Y, Belin RJ, Chen Y. Magnesium intake and the metabolic syndrome: epidemiologic evidence to date. J Cardiometab Syndr 2006; 1(5):351-355.

32. Hummel M, Standl E, Schnell O. Chromium in metabolic and cardiovascular disease. Horm Metab Res 2007; 39(10):743-751.

33. Santana-Galvez J, Cisneros-Zevallos L, Jacobo-Velazquez DA. Chlorogenic acid: recent advances on its dual role as a food additive and a nutraceutical agaist metabolic syndrome. Molecules 2017; 22:358.

34. Maeda H. Nutraceutical effects of fucoxanthin for obesity and diabetes therapy: a review. J Oleo Sci 2015; 64(2):125-132.

35. Millan J, Cicero AFG, Torres F, Anguera A. Effects of a nutraceutical combination containing berberine (BRB), policosanol, and red yeast rice (RYR), on lipid profile in hypercholesterolemic patients: a metaanalysis of randomized controlled trials. Clin Investig Arteriosclero 2016; 28 (4):178-187.
36. Ribas-Latre A, Eckel-Mahan K. Interdependence of nutrient metabolism and the circadian clock system: Importance for metabolic health. $\mathrm{Mol}$ Metab 2016; 5(3):133-152.

37. Desai M, Jellyman JK, Ross MG. Epigenomics, gestational programming and risk of metabolic syndrome. Int J Obes (Lond) 2015; 39(4):633-641.

38. Tarrade A, Panchenko P, Junien C, Gabory A. Placental contribution to nutritional programming of health and diseases: epigenetics and sexual dimorphism. J Exp Biol 2015; 218(Pt 1):50-58.

39. Brenseke B, Prater MR, Bahamonde J, Gutierrez JC. Current thoughts on maternal nutrition and fetal programming of the metabolic syndrome. J Pregnancy 2013:368461.

40. Knip M, Akerblom HK.Early nutrition and later diabetes risk. Adv Exp Med Biol 2005; 569:142-150.

41. Brown LD. Endocrine regulation of fetal skeletal muscle growth: impact on future metabolic health. J Endocrinol 2014; 221(2): R13-29.

42. DeBoer MD, Lima AA, Oría RB, Scharf RJ, Moore SR, Luna MA, Guerrant RL. Early childhood growth failure and the developmental origins of adult disease: do enteric infections and malnutrition increase risk for the metabolic syndrome? Nutr Rev 2012; 70(11): 642-653.

43. Alvisi P, Brusa S, Alboresi S, Amarri S, Bottau P, Cavagni G, Corradini B, Landi L, Loroni L, Marani M, et al. Recommendations on complementary feeding for healthy, full-term infants. Ital J Pediatr 2015; 41:36.

44. Sun, C. H., et al. (2011). The effect of vitamin-mineral supplementation on CRP and IL-6: a systemic review and meta-analysis of randomised controlled trials. Nutr Metab Cardiovasc Dis. 21(8):576-583. (Not referenced in the paper)
Nutrition and Dietary Supplements

\section{Publish your work in this journal}

Nutrition and Dietary Supplements is an international, peer-reviewed, open access journal focusing on research into nutritional requirements in health and disease, impact on metabolism and the identification and optimal use of dietary strategies and supplements necessary for normal growth and development. The journal welcomes submitted papers covering original research, basic science,

\section{Dovepress}

clinical \& epidemiological studies, reviews and evaluations, guidelines, expert opinion and commentary, case reports and extended reports. The manuscript management system is completely online and includes a very quick and fair peer-review system, which is all easy to use. Visit http://www.dovepress.com/ testimonials.php to read real quotes from published authors. 